\title{
Surgical Treatment of Pulmonary Metastasectomy: Analysis of 92 Cases
}

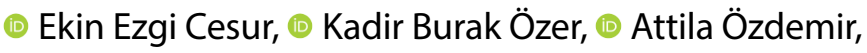 \\ 다 Fatma Tuğba Özlü, (1) Recep Demirhan
}

Department of Thoracic Surgery University of Health Sciences, Kartal Dr. Lütfi Kırdar Training and Research Hospital, İstanbul, Turkey

Submitted: 23.07 .2018 Accepted: 25.07.2018

Correspondence: Ekin Ezgi Cesur, SBÜ Kartal Dr. Lütfi Kırdar Eğitim ve Araştırma Hastanesi Göğüs Cerrahisi Kliniği, İstanbul, Turkey

E-mail: ezgicesur@gmail.com

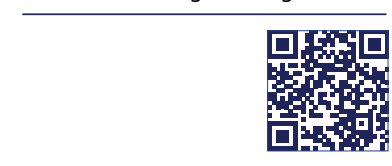

Keywords: Complete resection; disease-free survival; pulmonary metastasectomy.

\begin{abstract}
Objective: The lungs are the second most common site of metastasis, and for selected patients, pulmonary metastasectomy can be a curative option. The surgical goal is complete resection with minimal parenchymal loss in order to prolong life. In well-selected cases, minimally invasive approaches can increase quality of life and offer equivalent oncological outcomes.
\end{abstract}

Methods: Patients diagnosed with pulmonary metastasis who underwent a metastasectomy in a single hospital between January 2012 and December 2017 were evaluated retrospectively. A total of 92 patients ( 55 male and 37 female) underwent thoracotomy or thoracoscopy procedures with the goal of complete resection.

Results: Among the patients included in the study, 8 were symptomatic: cough was reported in 3, chest pain (pneumothorax) was experienced in 3, and hemoptysis occurred in 2 cases. The longest disease-free survival (DFS) period was seen in cases of epithelial tumor (40.I months) and sarcoma (28.2 months); the shortest survival was seen in those with germ cell tumor (8.3 months) and melanoma (8.I months).

Conclusion: Patients with pulmonary metastasis require a multidisciplinary approach for treatment. When the primary disease is under control and there is no other distant metastasis, metastasectomy with complete surgical resection can provide an extended period of DFS, particularly for patients with epithelial or sarcomatous tumors.

\section{INTRODUCTION}

The metastatic potential of malignant diseases is one of the most important challenges in cancer treatment. ${ }^{[1]}$ The lungs are a frequent site of metastasis; however, complete resection of pulmonary metastases can significantly affect survival. ${ }^{[2]}$ There is a survival advantage associated with isolated lung metastasis compared with other organ metastases, and pulmonary tumors respond very well to local and systemic treatment methods. ${ }^{[3]}$

Although there are different opinions among oncologists and surgeons concerning the decision if and when to perform a metastasectomy, the 5 years survival rate after complete resection has been reported to be between $20 \%$ and $40 \%$ in selected patients. ${ }^{[4]}$ Control of the primary tumor, and a lack of extrapulmonary metastasis, or when present, extrapulmonary metastasis that can be controlled, have been reported as important factors. ${ }^{[5,6]}$ Pulmonary metastasectomy is a well-known procedure that has been performed for many years. The prognostic factors affecting DFS include the extent of pulmonary metastasis, duration of disease-free survival, successful radical surgery, and the carcinoembryonic antigen level in colorectal cancers. ${ }^{[7]}$

Most often, patients with pulmonary metastasis are asymptomatic, but occasionally cough or hemoptysis may be seen in centrally located metastases. Most are diagnosed during primary tumor staging or follow-up. Computed tomography (CT) is the preferred means of diagnosis. Positron-emission tomography/CT or bone scintigraphy may also be used. A small number of metastases, DFS for more than 36 weeks, the ability to perform a complete resection, a lack of mediastinal lymph node involvement, 
and negative tumor markers are good prognostic factors. Mediastinal involvement, extrathoracic metastasis, incomplete surgery, a shorter DFS expectancy, and a shorter tumor doubling time reflect a poorer prognosis.

The most important goal of surgical procedures in these cases is to achieve complete resection with minimal loss of parenchyma. Enucleation with monopolar cautery, excision using energy devices, Nd-YAG laser, wedge resection, or anatomical resection may be applied. Minimally invasive methods that have been used in recent years include classic thoracotomy and bimanual palpation with metastasectomy, and less frequently, sternotomy and bilateral intervention.

The present study was an evaluation of the methods used to treat patients with pulmonary metastasis in the clinic of one hospital and an analysis of the survival results.

\section{MATERIAL AND METHODS}

In all, 92 patients with distant organ metastasis in the lung who underwent a metastasectomy between January 2012 and December 2017 at a single hospital were identified. The median age of the 55 men and 37 women was 41 years (range: 33-67 years). Clinical follow-up data, surgical details, and pathology reports were reviewed after receiving the approval of the ethics committee. Characteristics of age, sex, tumor histology, number of metastases, operative technique, and survival time were used to group the patients.

All of the patients were referred to us by oncology clinics after systemic screenings. PET/CT was initially used by the oncology clinic to evaluate pulmonary metastases, and thorax CT was used in the following months. The quantity, distribution, anatomical localization, and operability of pulmonary metastases were evaluated. After clinical and anesthesia evaluations, patients who had no medical contraindication for surgery and were suitable for complete resection based on a surgical evaluation were operated on.

A thoracotomy was performed in $84(91 \%)$ cases and a videothoracoscopy in 8 (9\%). Thin-section helical CT determined that the patients selected for videothoracoscopy had a single peripheral metastasis. Of the thoracotomy patients, II\% $(n=8)$ were a repeat thoracotomy procedure. Nine $(10 \%)$ patients underwent a bilateral, staged metastasectomy. In patients who underwent videothoracoscopy-aided metastasectomy, wedge resection was performed using an endostapler.

In cases of metastasectomy performed with a classic thoracotomy and bimanual palpation, monopolar cautery, energy device, enucleation, and wedge resection with a stapler were used at the site of metastasis to achieve complete resection with minimal parenchymal loss. In I case,
Table I. The distribution of the primary tumors

\begin{tabular}{lcc}
\hline Histological type of the tumors & $\mathbf{n}$ & $\%$ \\
\hline Colorectal tumor & 42 & 46 \\
Sarcoma & 14 & 15 \\
Breast carcinoma & 7 & 7 \\
Renal cell carcinoma & 6 & 6 \\
Malignant mesenchymal tumor & 5 & 5 \\
Bladder tumor & 4 & 4 \\
Testicular tumor & 4 & 4 \\
Choriocarcinoma & 2 & 2 \\
Malignant melanoma & 1 & 1 \\
Adenoid cystic carcinoma & 1 & 1 \\
\hline
\end{tabular}

lobectomy was performed because the tumor was large and centralized, and attacks of hemoptysis had been observed in the patient's clinical evaluation.

In the pulmonary metastasectomies performed, the distribution of the primary tumors was: colorectal cancer $(n=42 ; 46 \%)$, sarcomatous metastasis $(n=14 ; 15 \%)$, breast cancer metastasis $(n=7 ; 7 \%)$, renal cell carcinoma metastasis $(n=6 ; 6 \%)$, malignant mesenchymal tumor metastasis $(n=5 ; 5 \%)$, bladder tumor $(n=4 ; 4 \%)$, testicular tumor metastasis $(n=4 ; 4 \%)$, choriocarcinoma metastasis $(n=2$; $2 \%)$, malignant melanoma metastasis $(\mathrm{n}=1 ; 1 \%)$, and adenoid cystic carcinoma metastasis $(\mathrm{n}=\mathrm{I}$; I\%) (Table I).

An average of 4 (range: 4-8) metastatic foci were removed. When pulmonary metastases were radiologically observed, the mediastinal lymph nodes were removed, and mediastinal lymph node dissection was performed in cases with colorectal cancer metastases even if no pathological lymph nodes were observed radiologically. The analysis of the data was performed using the SPSS program and survival of the patients was assessed using Kaplan-Meier survival analysis.

\section{RESULTS}

Of the 92 patients who were enrolled in the study, 8 were symptomatic and the remaining 84 patients were asymptomatic. Chest pain was seen in 3 patients (pneumothorax), a cough in 3 , and hemoptysis in 2 .

The length of DFS varied according to the histopathological type of tumor: the mean for epithelial tumors was 40.1 months (range: 9-75.2 months), while it decreased to 28.2 months (range: 3-44.3 months) in cases of sarcomatous tumors, 8.3 months in germ cell tumors and 8.1 months in melanoma patients. In almost all $(90 \%)$ of those with an epithelial tumor histology, and $58 \%$ of the patients with sarcoma metastasis, the DFS was less than 12 months. 
In all, 22 of the cases had a single metastasis, while the remainder had multiple metastatic lesions. Patients with sarcoma and germ cell tumor metastasis were more likely to have a single metastasis, whereas multiple metastatic foci were detected in $82 \%$ of epithelial tumors. Cases of a solitary metastasis, no distant metastasis, and a controlled primary cancer were found to have a significantly higher I-year (83\%) and 2-year DFS (69\%) after complete resection when compared with those with multiple metastases $(p<0.05)$.

Eighty $(86.9 \%)$ patients underwent a single operation, while 10 underwent 2 surgeries, and 2 underwent 3 operations. The length of DFS did not differ significantly according to the number of operations, while mean survival time was significantly longer in patients who underwent multiple operations.

A significant difference in life span was observed in a comparison of the patients who underwent chemoradiotherapy before or after the operation and those who underwent just a metastasectomy operation. The 2-year and 5 -year survival rate of the chemoradiotherapy patients was $63.9 \%$ and $21.7 \%$, respectively, while the corresponding survival rate was $57.7 \%$ and $11.5 \%$ in the untreated cases $(p<0.012)$.

No instance of mortality was observed during the 92 operations included in the study. Morbidity was observed in 6 patients. There were 2 cases of cardiac arrhythmia (atrial fibrillation), a prolonged air leak was detected in 2, pneumonia in I, and pleurisy in I. There was no significant difference in the morbidity and mortality rates between cases of videothoracoscopic or thoracotomy procedure.

\section{DISCUSSION}

Distant organ metastasis is frequently seen in advanced stage malignant disease, followed by lung metastasis. Control of systemic metastasis is still controversial, and differences can be observed, especially in oncological and surgical approaches. Patients with metastases limited to the lungs have a better prognosis than those with multi-organ metastases.

Patients with pulmonary metastases are usually asymptomatic. The metastasis is usually detected in follow-up imaging studies, and the cases are directed by oncology clinics. Follow-up usually includes a thorax CT. PET/CT is another method used for diagnosis. Lucas et al. ${ }^{[8]}$ found a diagnostic sensitivity and specificity of PET in patients with pulmonary metastatic sarcoma of $86.9 \%$ and $100 \%$, respectively. In our study, we detected that diagnosis was made using PET/CT in $45 \%$ of the cases referred by oncology clinics, while thoracic CT was used in 55\%.

It has been reported that that a smaller number of metastatic nodules indicated a better prognosis. ${ }^{[3]}$ Our research revealed the largest quantity of nodules was detected in cases of sarcoma, with as many as 8 nodules resected at one time. Pastorino et al. ${ }^{[6]}$ found a 5 -year survival rate of $43 \%$ in cases with single metastasis, while it was $27 \%$ in patients with $\geq 4$ metastases. However, Monteiro et al..$^{[9]}$ and Robert et al. ${ }^{[5]}$ determined no significant correlation between survival rate and the number of nodules.

The histopathological type is an important prognostic factor in the survival of patients with pulmonary metastasis. In a study of some 5200 patients, Pastorino et al. ${ }^{[6]}$ indicated that germ cell tumors had the best survival rate, while melanoma cases had the worst survival rate. The mean length of survival for patients with epithelial tumors was 40 months, while it was 30 months for sarcoma, and 20 months for melanoma. ${ }^{[10]}$ In our study, the length of survival was greatest in cases of epithelial tumors and lowest in cases of melanoma, which was consistent with the literature. In this country, Evman et al. ${ }^{[12]}$ researched I 26 metastasectomy operations and detected the greatest survival in cases with epithelial tumors.

The most common tumors in our study were epithelial tumors and they were also the group for which metastasectomy had the greatest effect in terms of DFS. As we could not obtain information about the 10-year survival rate of the patients in this study, the 2-year and 5 -year survival rates were calculated. The results indicated a 2 -year rate of $63.9 \%$ and a 5 -year rate of $21.7 \%$ in cases of epithelial tumor, while it was $54.9 \%$ and $10.1 \%$, respectively, in sarcoma patients. The mean DFS was 40.I months in patients with epithelial tumors and 28.2 months in sarcoma cases. Metastasectomy contributes directly to survival, particularly in cases of epithelial and sarcomatous tumors.

Pastorino et al. ${ }^{[6]}$ reported that survival was longer in patients who underwent multiple operations due to pulmonary metastasis compared with a single metastasectomy operation. In our study, the 2-year and 5-year survival rates of metastatic cases with multiple operations were found to be greater than those of cases who underwent a single operation in accordance with the literature findings.

The use of systemic chemoradiotherapy to control the disease in pulmonary metastasis patients is the basis of treatment. While the postoperative role of chemoradiotherapy is still controversial, Marina et al. ${ }^{[1]}$ reported that chemotherapy administered after a complete surgical resection had demonstrated positive contributions to survival. In our study, the survival rates of the patients who received concurrent or postoperative chemoradiotherapy were significantly greater than those of the untreated patient group. 


\section{CONCLUSION}

Patients with pulmonary metastasis require a multidisciplinary treatment approach. In cases without distant metastasis and in which the primary disease is under control, we believe that metastasectomy can contribute significantly to DFS if complete surgical resection is possible, and particularly in cases of epithelial and sarcomatous tumors.

Ethics Committee Approval

Approved by the local ethics committee.

Informed Consent

Retrospective study.

Peer-review

Internally peer-reviewed.

Authorship Contributions

Concept: R.D..; Design: E.E.C.; Data collection \&/or processing: K.B.O.; Analysis and/or interpretation: F.T.O.; Literature search: A.O.; Writing: E.E.C.; Critical review: R.D.

Conflict of Interest

None declared.

\section{REFERENCES}

1. Hornbeck K, Ravn J, Steinbruchel DA. Current status of pulmonary metastasectomy. European Journal of Cardio-Thoracic Surgery 2011;39:955-62. [CrossRef]

2. Abecasis N, Cortez F, Bettencourt A, Costa CS, Orvalho F, de Almeida JM. Surgical treatment of lung metastases: prognostic factors for long-term survival. J Surg Oncol 1999;72:193-8. [CrossRef]
3. Putnam JB. Secondary tumors of the lung. In: Shields TW, Locicero J, Ponn RB, editors. General thoracic surgery. 5th ed. Philadelphia: Lippincott Williams \& Wilkins; 2000, p. 1555-76.

4. Şengül AT, Başoğlu A, Büyükkarabacak AB, Yetim TD, Kutlu T. Assessment of metastasectomy and prognostic factors in the treatment of metastatic lung tumors [Article in Turkish]. Türk Göğüs Kalp Damar Cer Derg 2009;17:87-91.

5. Robert JH, Ambrogi V, Mermillod B, Dahabreh D, Goldstraw P. Factors influencing long-term survival after lung metastasectomy. Ann Thorac Surg 1997;63:777-84. [CrossRef]

6. Pastorino U, Buyse M, Friedel G, Ginsberg RJ, Girard P, Goldstraw $\mathrm{P}$, et al; International Registry of Lung Metastases. Long-term results of lung metastasectomy: prognostic analyses based on 5206 cases. J Thorac Cardiovasc Surg 1997;113:37-49. [CrossRef]

7. Petrella F, Diotti C, Rimessi A, Spaggiari L. Pulmonary Metastasectomy: an overview. J Thorac Dis 2017;9:S1291-8. [CrossRef]

8. Lucas JD, O’Doherty MJ, Wong JC, Bingham JB, McKee PH, Fletcher CD, et al. Evaluation of fluorodeoxyglucose positron emission tomography in the management of soft-tissue sarcomas. J Bone Joint Surg Br 1998;80:441-7. [CrossRef]

9. Monteiro A, Arce N, Bernardo J, Eugénio L, Antunes MJ. Surgical resection of lung metastases from epithelial tumors. Ann Thorac Surg 2004;77:431-7. [CrossRef]

10. Turna A, İşcan M. Lymphdenectomy in Patients Undergoing Pulmonary Metastasectomy [Article in Turkish]. Turkiye Klinikleri J Thor Surg-Special Topics 2017;8:411-4.

11. Marina NM, Pratt CB, Rao BN, Shema SJ, Meyer WH. Improved prognosis of children with osteosarcoma metastatic to the lung(s) at the time of diagnosis. Cancer 1992;70:2722-7. [CrossRef]

12. Evman S, Demirhan R, Çardak E, Özer KB. Who Actually Profits From Pulmonary Metastasectomy Operation? Retrospective Analysis of 12 Years. Eurasian J Pulmonol 2014;16:164-8. [CrossRef]

\section{Pulmoner Metastazektomilerde Cerrahi Tedavi: 92 Olgu Analizi}

Amaç: Akciğer, tüm vücut kanserleri için ikinci en sık metastaz organı olup seçilmiş hastalarda pulmoner metastazektomi küratif seçenektir. Operatif yaklaşımda temel amaç en az parankim kaybı ile komplet rezeksiyon yapmak ve doğru hasta seçimi ile sağ kalım süresini uzatmaktır. İyi seçilmiş hastalarda minimal invaziv girişimler hastanın ameliyat sonrası yaşam kalitesini, eşit onkolojik sonuçlarla artırabilmektedir.

Gereç ve Yöntem: Ocak 20I2-Aralık 2017 tarihleri arasında pulmoner metastaz tanısı ile kliniğimizde metastazektomi yapılan hastalar incelendi. Klinik değerlendirme sonrasında pulmoner rezeksiyona uygun olan 92 hasta (55 erkek ve 37 kadın) operasyona hazırlandı. Torakotomi ve torakoskopi prosedürleri ile cerrahi uygulanan hastalarda komplet rezeksiyon amaçlandı.

Bulgular: Çalışmamıza alınan hastalar başvuru anında semptomlar açısından değerlendirildiğinde, 8 olgu semptomlu olarak saptandı ve bunlardan 3'ünde öksürük, 3'ünde göğüs ağrısı (pnömotoraks nedeni ile) mevcuttu. Histopatolojik tip ile hastalıksız yaşam süresi değerlendirmesinde ise en yüksek yaşam süresi epiteltal tümörlerde (40.I ay) ve sarkomlarda (28.2 ay) saptanırken, germ hücreli tümörlerde ( 8.3 ay) ve melanomlarda (8.I) ise en düşük olarak izlendi.

Sonuç: Multidisipliner bir tedavi yaklaşımı gerektiren pulmoner metastazlı hastaların; primer hastalı̆ı kontrol altında, uzak metastazı olmayıp ve komplet cerrahi rezeksiyon uygulanabiliyor ise özellikle epitelyal tip ve sarkom tipi tümörlerde metastazektominin hastalıksız yaşam süresine ve ortalama sağkalıma ciddi katkısı olduğu kanaatindeyiz.

Anahtar Sözcükler: Hastalıksız yaşam süresi; komplet rezeksiyon; pulmoner metastazektomi; sağkalım. 